\section{Macrolgae as an indicator of the environmental health of the Pirangi reefs, Rio Grande do Norte, Brazil}

\author{
Carolina A. A. Azevedo, Marcella A. A. Carneiro, Sérgio R. \\ Oliveira, Eliane Marinho-Soriano*
}

Laboratório de Macroalgas, Departamento de Oceanografia e Limnologia, Universidade Federal do Rio Grande do Norte.
Revista Brasileira de Farmacognosia Brazilian Journal of Pharmacognosy 21(2): 323-328, Mar./Apr. 2011

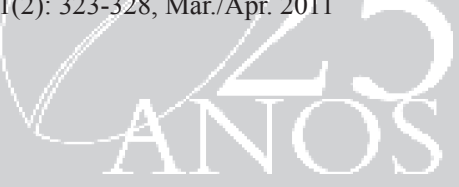

\section{Article}

\begin{abstract}
The coral reefs of Pirangi beach have suffered the impact of anthropic actions, mainly those related to tourism. To evaluate these effects, algal samples were collected at nine stations, distributed along the reef fringe. The macrobenthic community (algae/coral) was identified through photographic methods. A total of thirty species of algae, five species of coral, and one species of mollusk were identified. In areas of intense tourist activity, small algae were predominant, while in areas without human interference, foliose algae were predominant. Cluster analysis of the organisms revealed a pattern in spatial distribution into five zones: (1) a submerged zone with very diverse flora, (2) a zone with a predominance of Caulerpa racemosa, (3) a zone with high coverage of Sargassum vulgare, (4) a trampled zone with bare spaces, small algae and Zoanthus sociatus, and (5) a zone with predominance of Palythoa caribaeroum. The results show that human disturbances of the natural order can result in a different distribution model for benthic organisms in reefs. Moreover, these results allow us to infer that the area studied has undergone changes resulting from human activities and that the differences in biological composition can be used as an important indicator of the health of the Pirangi reef.
\end{abstract}

Received 13 Jan 2011

Accepted 25 Jan 2011 Available online 22 Apr 2011

Keywords: reef macroalgae coral diversity degradation conservation

ISSN $0102-695 \mathrm{X}$ doi: 10.1590/S0102-695X2011005000071

\section{Introduction}

Reef areas worldwide are under constant stress due to human activities, including eutrophication, overfishing, tourism, and sedimentation resulting from land use practices (Bellwood et al., 2004; Smith et al., 2006). In recent years, recreational activities in marine environments have increased worldwide (Werfhrost \& Pearse, 2007). Human interferences on coral reef create disturbances to marine organisms, which include the harvest of animals, the modification of habitat, the trampling and the physical contact of the fins of divers with the organisms (Addessi, 1994). These activities can cause high mortality in marine organisms, with sessile invertebrates and marine algae being the most vulnerable (Milazzo et al., 2002).

Brazilian reefs have suffered disturbances, particularly those that are close to urban areas and easily accessible (Castro \& Pires, 2001). In reef areas on the Northeastern coast of Brazil, there are records from the seventeenth century of coral and sandstone block extraction for use in construction (Ferreira \& Maida, 2006). For many years, coral organisms were also exploited to produce lime, an activity that ended in the 1970s. Predatory fishing and tourism have also contributed to the degradation of these environments.

The negative impacts caused by human activities highlight the need for methodologies that quickly describe biological communities and serve as a basis for monitoring and conservation programs (Pereira et al., 2008). Among the techniques used to measure the biological composition of reef formations are the destructive methods, which include the removal of organisms, and the non-destructive methods, which consist of counting the organisms and coverage percentage. Recently, photoquadrat sampling techniques have been widely used in various regions of the world. This method can be applied to quantify the coverage and density of algae and invertebrates for monitoring, environmental impact and baseline studies, etc. This method is suitable for diagnosis and monitoring of large areas and has the advantage of obtaining a large number of sample elements. The objectives of this study are to characterize the algal community on the Pirangi reef area and to identify evidence of human impacts through the comparison of areas subjected to a gradient of human interference. 


\section{Materials and Methods}

The present study was conducted on the Pirangi reefs, located on the southern coast of Rio Grande do Norte state $\left(5^{\circ} 58^{\prime} \mathrm{S}-35^{\circ} 06^{\prime} \mathrm{W}\right)$, in Northeastern Brazil (Figure 1). This reef formation is about $2000 \mathrm{~m}$ long and $500 \mathrm{~m}$ wide and is part of a discontinuous reef system that extends over a large part of the coast of Rio Grande do Norte. The reef area studied is about $1 \mathrm{~km}^{2}$ and approximately $800 \mathrm{~m}$ from shore. The depth in the vicinity of the reef does not exceed $2 \mathrm{~m}$ during low tides. Water temperature is relatively constant throughout the year $\left(28\right.$ to $\left.29^{\circ} \mathrm{C}\right)$ and the tidal range varies from 0.1 to $2.7 \mathrm{~m}$. The presence of shallow, clear, warm water throughout the entire year and the relative proximity of the coast have provided and incentive to marine tourism for over 20 years. The recreational tourist activity on the reef occurs throughout the year, with peaks in January, February and July.

In this study, nine sampling stations (E1 to E9) were selected along the reef (north to south) using a GPS (Global Positioning System), the selection contemplating areas that are frequently visited by tourists, areas with little tourist activity, and areas totally free of the presence of tourists. The stations where no tourism is practiced were located at both ends of the reef (E1, E2, E3, E8, and E9). These areas are always submerged, even in exceptional tides. Two stations (E5 and E6) were located on the reef plateau in areas of intense human activity, suffer constant trampling and are immersed in spring tides. The other two stations (E4 and E7) were located in areas where the impact of tourism is considered to be relatively moderate. Station E4 is sheltered from the brunt of the waves, while E7 is on the exposed portion of the reef and subject to constant pounding of the waves. Samples were taken between February and March, 2010, during low tide.

The macrobenthic community (algae/ invertebrates) was identified by the photoquadrat method
(Preskitt et al., 2004), with 50-meter transects distributed randomly and parallel to the coastline, using digital photographs taken at 2-meter intervals. A digital camera in an underwater housing was used, coupled with a stand that guaranteed a $90^{\circ}$ angle to the substrate. Subsequently, each photograph was analyzed using CPCe 3.5 software (Coral Point Count with Excel Extensions) with a grid with 70 intersection points (Kohler \& Gill, 2006). Each point was identified with a corresponding category. The general categories assessed were corals, mollusks, crustose coralline algae, articulated coralline algae, green algae, red algae, brown algae, and sand/gravel/rock. Each general category was composed of several sub-categories, consisting of the different species of organisms identified at the lowest possible taxonomic level.

The benthic groups were analyzed by taxonomic composition, species richness, Shannon-Wiener diversity, and coverage percentage. The differences between richness indices at different collection stations were investigated by variance analysis (one way ANOVA), using Tukey's a posteriori test. Univariate analyses were conducted according to Zar (2009), with the aid of Sigma Stat 3.0 software. Comparative analysis of the stations studied included cluster analysis (Q mode) and the MDS ordering method, using the Bray-Curtis coefficient, conducted with Primer 5 software (Clarke \& Warwick, 2001).

\section{Results}

In this study, differences were recorded in the species composition. A total of 36 species were identified during the study, including thirty species of algae, five species of coral, and one species of mollusk (Table 1). The data showed that algae were the dominant organisms on the reef formation. Caulerpa, Gelidium, and Dictyota presented the largest number of species (3 each), with Gelidiella acerosa showing a wider distribution along the reef, being present at eight of the

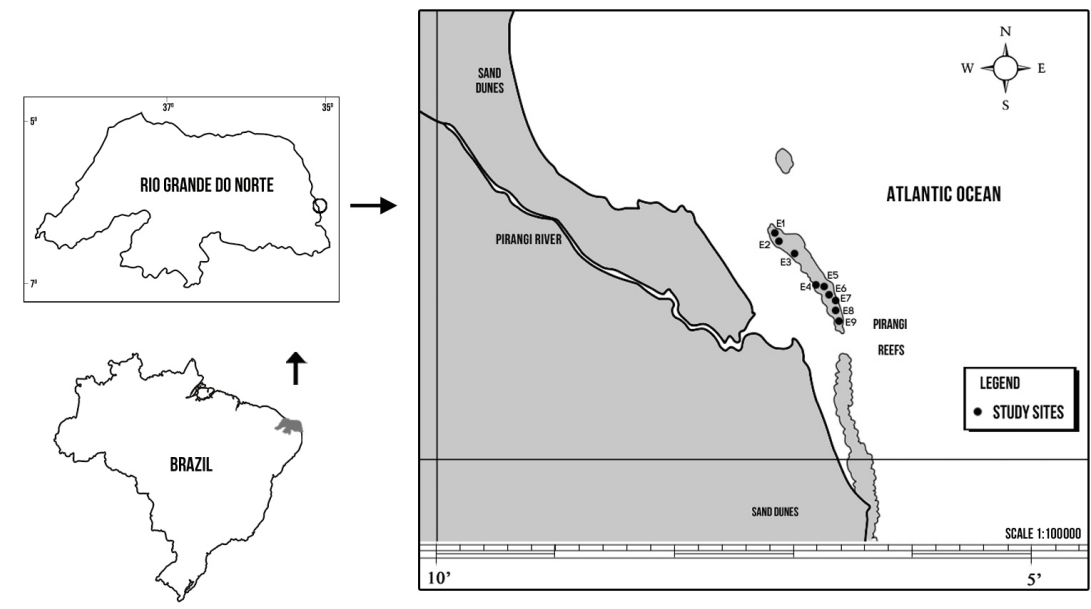

Figure 1. Study area showing the sampling stations. 
sampling stations. Among the coral species, Siderastrea stellata and Zoanthus sociatus were present at four and five of the stations, respectively. The richness index differed significantly between the stations analyzed $(p \leq 0.001)$. As expected, the stations that showed the highest richness indices for algae were found in the areas where there was no tourist activity, while those that had the lowest values were located in areas with moderate and heavy tourist activity (Figure 2).

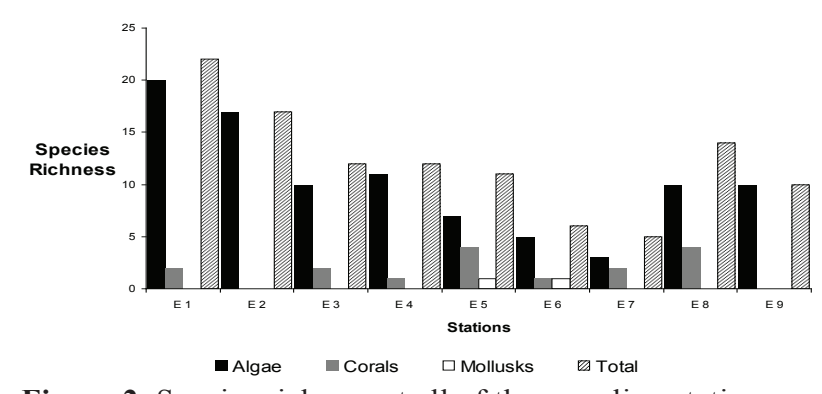

Figure 2. Species richness at all of the sampling stations.

Table 1. Percent coverage by benthic organisms at the nine stations on the Pirangi reef.

\begin{tabular}{|c|c|c|c|c|c|c|c|c|c|}
\hline \multirow{2}{*}{ Categories } & \multicolumn{9}{|c|}{ Stations } \\
\hline & E 1 & E 2 & E 3 & E 4 & E 5 & E 6 & E 7 & E 8 & E 9 \\
\hline Green articulated & 0.00 & 0.00 & 0.00 & 0.00 & 0.00 & 0.00 & 0.00 & 0.00 & 0.00 \\
\hline Articulated coralline & 0.06 & 0.00 & 0.00 & 0.00 & 6.51 & 0.23 & 0.00 & 0.00 & 0.17 \\
\hline Crustose coralline & 1.43 & 3.49 & 18.86 & 2.29 & 1.14 & 0.30 & 1.31 & 2.40 & 11.60 \\
\hline Caulerpa mexicana & 0.69 & 0.17 & 3.71 & 0.00 & 0.00 & 0.00 & 0.00 & 0.00 & 0.06 \\
\hline Caulerpa prolifera & 0.00 & 0.80 & 0.00 & 0.00 & 0.00 & 0.00 & 0.00 & 0.00 & 1.54 \\
\hline Caulerpa racemosa & 7.49 & 5.09 & 46.86 & 0.06 & 0.00 & 0.00 & 0.11 & 0.00 & 0.51 \\
\hline Codium isthmocladum & 1.54 & 0.00 & 0.00 & 0.00 & 0.00 & 0.00 & 0.00 & 0.00 & 0.11 \\
\hline Dictyosphaeria versluysii & 0.00 & 0.00 & 0.00 & 0.00 & 2.34 & 0.60 & 0.00 & 0.34 & 0.00 \\
\hline Acantophora spicifera & 0.00 & 0.00 & 0.00 & 0.00 & 1.49 & 0.00 & 0.00 & 0.00 & 0.00 \\
\hline Botryocladia occidentalis & 0.17 & 0.17 & 0.06 & 0.00 & 0.00 & 0.00 & 0.00 & 0.00 & 0.00 \\
\hline Bryothamnium seafortii & 0.29 & 2.74 & 0.00 & 0.06 & 0.00 & 0.00 & 0.00 & 0.00 & 0.23 \\
\hline Bryothamnium triquetrum & 2.06 & 5.71 & 0.06 & 0.00 & 0.00 & 0.00 & 0.00 & 0.00 & 0.00 \\
\hline Laurencia sp. & 0.86 & 0.11 & 0.00 & 0.00 & 3.26 & 0.00 & 0.00 & 0.00 & 0.11 \\
\hline Gelidiella acerosa & 1.09 & 1.03 & 0.11 & 0.46 & 21.83 & 5.34 & 0.00 & 0.63 & 0.23 \\
\hline Gelidium americanum & 2.97 & 0.06 & 0.00 & 0.00 & 0.00 & 7.67 & 0.00 & 3.09 & 0.51 \\
\hline Gelidium coarctatum & 0.06 & 0.00 & 0.00 & 0.34 & 0.00 & 0.00 & 0.00 & 0.11 & 0.00 \\
\hline Gelidium torulosum & 0.00 & 0.00 & 0.00 & 0.00 & 0.00 & 0.00 & 0.00 & 12.34 & 0.00 \\
\hline Gracilaria cervicornis & 0.00 & 0.00 & 0.00 & 1.66 & 0.00 & 0.00 & 0.00 & 0.00 & 0.00 \\
\hline Hypnea spinella & 0.00 & 0.00 & 0.00 & 0.00 & 0.29 & 0.00 & 0.00 & 0.00 & 0.00 \\
\hline Ochtodes secundirama & 0.00 & 0.00 & 1.20 & 0.00 & 0.00 & 0.00 & 0.00 & 0.00 & 1.83 \\
\hline Gelidium sp. & 0.00 & 0.00 & 0.00 & 0.00 & 0.00 & 0.00 & 48.57 & 0.00 & 0.00 \\
\hline Colpomenia sinuosa & 0.00 & 0.00 & 0.00 & 0.00 & 0.00 & 0.00 & 0.00 & 0.00 & 0.06 \\
\hline Dictyopteris delicatula & 20.57 & 15.09 & 24.80 & 22.46 & 0.00 & 0.00 & 0.00 & 33.43 & 18.40 \\
\hline Dictyota cervicornis & 0.46 & 0.00 & 0.00 & 0.00 & 0.00 & 0.00 & 0.00 & 0.00 & 0.00 \\
\hline Dictyota menstrualis & 2.17 & 1.77 & 0.00 & 1.20 & 0.00 & 0.00 & 0.00 & 0.11 & 7.14 \\
\hline Dictyota mertensii & 6.17 & 5.66 & 0.23 & 0.11 & 0.00 & 0.00 & 0.00 & 2.51 & 2.74 \\
\hline Dictyota pulchella & 0.23 & 0.11 & 0.00 & 0.00 & 0.00 & 0.00 & 0.00 & 0.00 & 0.06 \\
\hline Lobophora variegata & 0.74 & 2.23 & 0.00 & 2.57 & 0.00 & 0.00 & 0.00 & 0.00 & 8.29 \\
\hline Padina gymnospora & 0.00 & 0.00 & 0.00 & 0.00 & 0.00 & 0.00 & 0.00 & 0.00 & 0.80 \\
\hline Sargassum vulgare & 47.49 & 50.11 & 1.54 & 58.51 & 0.00 & 0.00 & 0.00 & 16.91 & 37.20 \\
\hline Spatoglossum schroederi & 0.46 & 4.00 & 0.00 & 0.00 & 0.00 & 0.00 & 0.00 & 0.00 & 1.14 \\
\hline Millepora alcicornis & 0.00 & 0.00 & 0.00 & 1.09 & 0.06 & 0.00 & 0.00 & 0.00 & 0.00 \\
\hline Palythoa caribaeroum & 0.00 & 0.00 & 0.00 & 0.00 & 0.00 & 0.00 & 49.20 & 1.71 & 0.00 \\
\hline Protopalythoa variabilis & 0.29 & 0.00 & 0.00 & 0.00 & 0.11 & 0.00 & 0.00 & 1.43 & 0.00 \\
\hline Siderastrea stellata & 0.06 & 0.00 & 0.97 & 0.00 & 0.23 & 0.00 & 0.00 & 0.86 & 0.00 \\
\hline Zoanthus sociatus & 0.00 & 0.00 & 0.17 & 0.00 & 32.57 & 24.51 & 0.51 & 3.31 & 0.00 \\
\hline Cerithium sp. & 0.00 & 0.00 & 0.00 & 0.00 & 0.11 & 0.08 & 0.00 & 0.00 & 0.00 \\
\hline
\end{tabular}


With respect to substrate coverage (Figure 3), brown algae had the highest coverage percentage at stations E1, E2, E4, E8, and E9, with the highest value recorded at station E4 $(84.86 \%)$. This dense coverage was mainly dominated by Sargassum vulgare (58.51\%), Dictyopteris delicatula (22.46\%), and Lobophora variegata $(2.57 \%)$. Sand/gravel/rock was predominant at stations E5 and E6, being particularly noteworthy (61.28\%) at station E6. At these two stations, the mollusk (Cerithium sp.) contributed to $0.11 \%$ (E6) and $0.08 \%$ (E5) of the coverage, respectively. Furthermore, the green algae Dictyosphaeria verlusyii were often observed at these stations $(2.34 \%)$. Red algae were significantly present at station E7 (48.57\%); however, this category was present in all of the reef areas sampled. Considerable coverage by corals was observed mainly at stations E5 (32.97\%) and E7 (49.89\%). The principal representatives were the species Zoanthus sociatus (E5) and Pallythoa caribaeroum (E7), respectively. High coverage by green alga was recorded at station E3 (50.57\%), where the most conspicuous species was Caulerpa racemosa (46.86\%). At the other stations, this category showed values below $10 \%$. Even at this station, the coverage by calcareous alga showed a maximum percentage of $18.86 \%$. Articulated coralline algae contributed to a low level of coverage, being present mainly at stations E5 (6.51\%) and E6 (0.23\%) (Table 1).

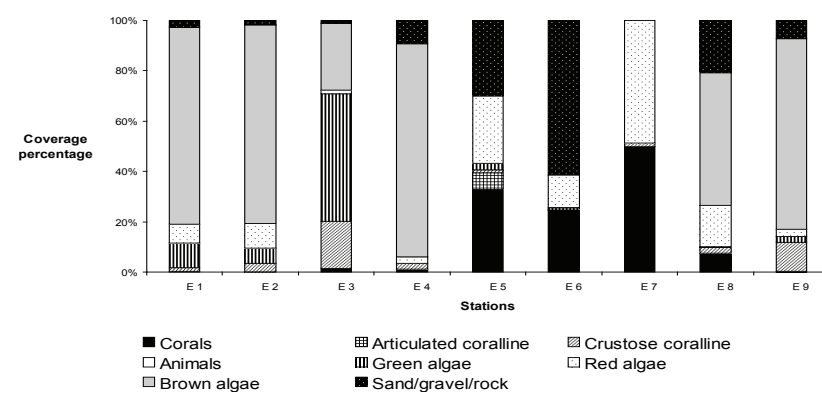

Figure 3. Percentages of coverage of the substrate in the study areas.

The Shannon-Wiener diversity indices of the Pirangi reef are shown in Figure 4. In general, the highest diversity values were recorded at stations located outside the area frequented by tourists and the lowest values in the areas with the greatest concentration of tourist activity. However, two notable exceptions are station E7, situated in an area with moderate human presence and which had the lowest recorded index (0.80), and station E5, where the diversity was higher than expected (1.40) due to the level of tourist activity and trampling.

Cluster analysis resulted in the grouping of the stations into five major groups at a similarity of $50 \%$ (Figure 5), which can be regarded as separate zones of the Pirangi reef formation. The first zone includes stations that are always submerged and characterized by thick algae and high species richness (E1, E2, E4, and E9). This zone has a high percentage of Sargassum vulgare. The second zone corresponds to station E3, also submerged, with high coverage of Caulerpa racemosa, followed by Dictyopteris delicatula; the third zone contains station E8, the only sampling location having considerable amounts of Gelidium torulosum; the fourth zone corresponds to the region of the reefs that periodically emerged at low tide (E5 and E6). This zone features small algae, low richness, and high coverage of Zoanthus sociatus; the fifth zone consists of station E7, exposed to the action of the waves, with low richness and high coverage by Gelidium sp. algae and Palythoa caribaeroum coral.

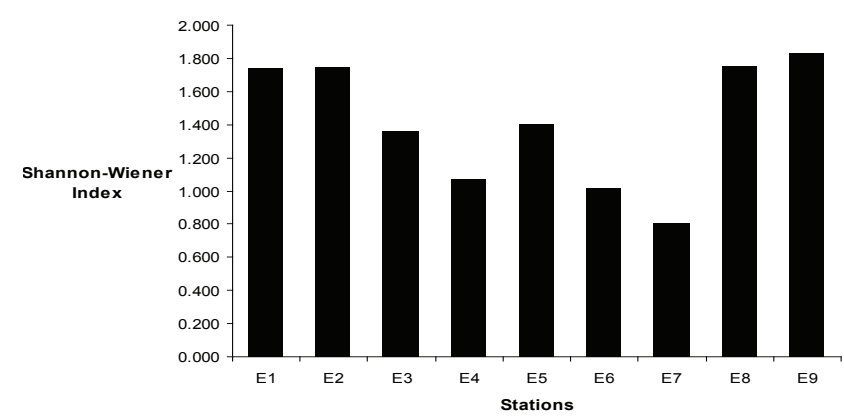

Figure 4. Shannon-Wiener diversity index values obtained at the sampling stations.

\section{Discussion}

This study identified macroalgae as the dominant biological component in the Pirangi reef formations. This feature is a relatively common phenomenon in reef environments located near urban areas in various regions of the world (Wismer et al., 2009). Moreover, comparison with data from the literature indicates that this model is quite common in reef areas on the Brazilian coast (Villaça \& Pitombo, 1997; Costa Jr. et al., 2000; Medeiros et al., 2010).

Substrate coverage along the reef fringe was predominantly composed of leafy algae, mostly belonging to the brown algae group (Sargassum, Dictyota and Dictyopteris). The abundance of brown algae is very common in shallow reefs (McCook, 1997), corroborating data obtained in this study. The dominance of brown algae was also described as a frequent component in reef areas of Northeastern Brazil (Figueiredo, 2000; Costa Júnior et al., 2002; Marins et al., 2008). In terms of coverage percentage, corals were well below macroalgae and the presence or absence of these organisms in a particular area of the reef was subject to environmental conditions (exposed, semiexposed, sheltered). For example, the species Pallythoa caribaeroum accounted for about $50 \%$ of the coverage percentage at station E7, an area subject to strong breaking waves, while Zoanthus sociatus had around 33\% coverage at station E5 and $24.5 \%$ at station E6, both characterized 


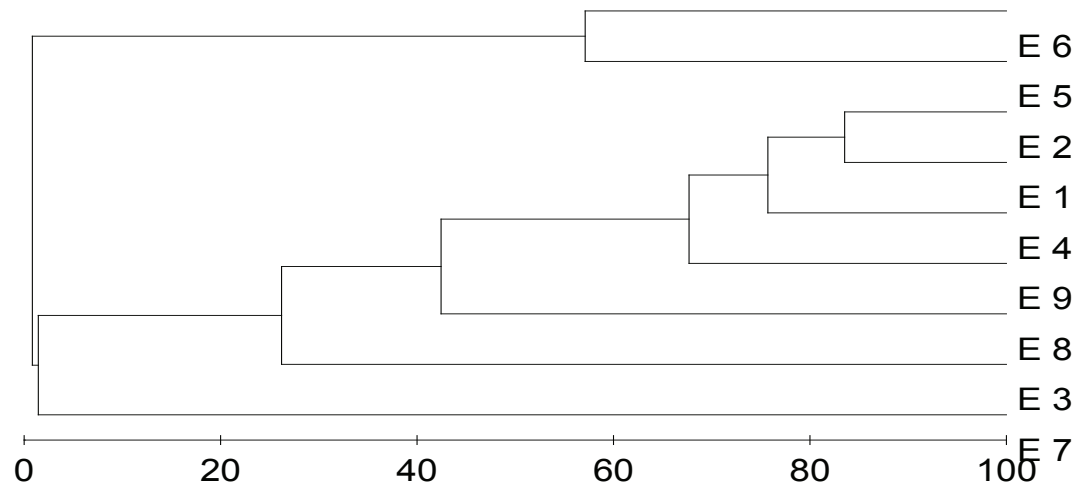

Figure 5. Cluster analysis based on the biological composition of the sampling stations.

by long periods of emersion, desiccation, and large changes in environmental factors. Indeed, studies have shown that zoanthids are conspicuous inhabitants of turbulent tropical waters, quite tolerant to physicalchemical stress, and can withstand prolonged periods of emersion (Bastidas \& Bone, 1996). Although present at four of the stations sampled, Sideratrea stellata colonies exhibited low coverage percentage (0.86-0.97\%). This species appears in higher proportion in submerged areas ( $\sim 2 \mathrm{~m}$ deep) located at both ends of the reef, where there is no tourist activity. This suggests that hydrodynamic exposure is a factor that influences the spatial variation of coral and indicates that soft coral communities are more flexible and resilient than hard coral communities to the environmental conditions of the reef.

Another interesting aspect of this study was the significant presence of small turf algae in areas where there is intense tourist activity (stations E5 and E6). The presence of these algae is indicative of environments subject to frequent disturbance and can be considered to be an indicator of reef degradation (Bahartan et al., 2010). The large areas with no living organisms in this zone further highlight the impact of human presence in this part of the reef.

Due to their proximity to the coast, the Pirangi reefs are particularly vulnerable to anthropogenic effects. One of these is the trampling of the biological coverage by the hundreds of visitors who frequent the reef each year. Thus, the data obtained in this study show that disturbances (natural or anthropogenic) can result in a different distribution of the benthic organisms in the reef area, as evidenced by the differences in diversity and coverage percentage among the stations studied. Moreover, these results allow us to infer that the area of the reef that was studied has undergone changes resulting from human activities and that the differences in biological composition can be used as an important indicator of the health of the Pirangi reef formation.

\section{References}

Addessi L 1994. Human disturbance and long-term changes on a rocky intertidal community. Ecol Appl 4: 786797.

Bahartan K, Zibdah M, Ahmed Y, Israel A, Brickner I, Abelson A 2010. Macroalgae in the coral reefs of Eilat (Gulf of Aqaba, Red Sea) as a possible indicator of reef degradation. Mar Pollut Bull 60: 759-764.

Bastidas C, Bone D 1996. Competitive strategies between Palythoa caribaeorum and Zoanthus sociatus (Cnidaria:Anthozoa) at a reef flat environmental in Venezuela. Bull Mar Sci 59: 543-555.

Bellwood DR, Hughes TP, Folke C, Nystrom M 2004. Confronting the coral reef crisis. Nature 429: $827-$ 833.

Castro CB, Pires DO 2001. Brazilian coral reefs: what we already know and what is still missing. Bull Mar Sci 69: 357-371.

Clarke KR, Warwick RM 2001. Chance in marine communities: An approach to statistical analysis and interpretation. Plymouth: Primer-E.

Costa Jr OS, Attrill MJ, Pedrini AG, De-Paula JC 2002. Spatial and seasonal distribution of seaweeds on coral reefs from Southern Bahia, Brazil. Bot Mar 45: 346-355.

Ferreira BP, Maida M 2006. Monitoramento dos recifes de coral do Brasil. Brasília: Ministério do Meio Ambiente, Série Biodiversidade 18.

Figueiredo MAO 2000. Recifes de corais ou recifes de algas? Ciência Hoje $n^{\circ}$ 166, 28: 74-76.

Kohler KE \& Gill SM 2006. Coral point count with excel extensions (CPCe): A visual basic program for the determination of coral and substrate coverage using random point count methodology. Comput Geosci 32: 1259-1269.

Marins BV, Brasileiro PS, Barreto MBB, Nunes JMC, YoneshigueValentin Y, Amado FGM 2008. Subtidal benthic marine algae of the Todos os Santos Bay, Bahia State, Brazil. Oecol Brasiliensis 12: 229-242.

McCook LJ 1997. Effects of herbivory on zonation of Sargassum spp. within fringing reefs of the central Great Barrier Reef. Mar Biol 129: 713-722.

Medeiros PR, Grempel RG, Souza AT, Ilarri M I, Rosa RS 2010. Non-random reef use by fishes at two dominant zones 
in a tropical, algal-dominated coastal reef. Environ Biol Fishes 87: 237-246.

Milazzo M, Chemello R, Badalamenti F, Camarda R, Riggio S 2002. The impact of human recreational activities in Marine Protected Areas: What lessons should be learnt in the Mediterranean Sea? Mar Ecol 23: 280-290.

Pereira FGH, Ghilardi NP, Fluckiger G, Berchez F 2008. Quantitative approach to the "Physiognomic assessment of hard bottom marine benthic communities" method: precision analysis. Oecol Brasiliensis 12: 191-196.

Preskitt LB, Vroom PS, Smith, C M 2004. A rapid ecological assessment (REA) quantitative survey method for benthic algae using photoquadrats with scuba. Pac Sci 58: 201-209.

Smith JE, Shaw M, Edwards RA, Obura D, Pantos O, Sala E, Sandin SA, Smriga S, Hatay M, Rohwer FL 2006. Indirect effects of algae on coral: algae-mediated, microbeinduced coral mortality. Ecol Lett 9: 835-845.

Villaça RC, Pitombo FB 1997. Benthic communities of shallowwater reefs of Abrolhos, Brazil. Rev Bras Oceanogr 45:
35-43.

Welfhorst LCV, Pearse J S 2007. Trampling in the rocky intertidal of Central California: a follow-up study. Bull Mar Sci 81: 245-254.

Wismer S, Hoey AS, Bellwood DR 2009. Cross-shelf benthic community structure on the Great Barrier Reef: relationships between macroalgal cover and herbivore biomass. Mar Ecol 376: 45-54.

Zar JH 2009. Biostatistical Analysis. New Jersey: Prentice Hall.

\section{*Correspondence}

Eliane Marinho-Soriano

Laboratório de Macroalgas, Departamento de Oceanografia e Limnologia, Universidade Federal do Rio Grande do Norte

Via Costeira s/n, Praia de Mãe Luíza, 59014-100 Natal-RN, Brazil

eliane@ufrnet.br

Tel. +558433424950 